The Effect of Timeliness and Credit Ratings on the Information Content of Earnings Announcements

\author{
STERGIOS LEVENTIS* \\ School of Economics, Business Administration and Legal Studies \\ International Hellenic University \\ 14th klm Thessaloniki-Moudania \\ 57101 Thessaloniki \\ Greece \\ and Aston Business School, UK \\ Tel: $+30231080-7541$ \\ Fax: +30 231 047-4520 \\ E-mail: s.leventis@ihu.edu.gr
APOSTOLOS DASILAS
School of Economics, Business Administration and Legal Studies
International Hellenic University
14th klm Thessaloniki-Moudania 57101 Thessaloniki
Greece
Tel: +30-231 080-7544
Fax: +30 231 047-4520
E-mail: a.dasilas@ihu.edu.gr
STEPHEN OWUSU-ANSAH
School of Business
Dominion University College
Accra
Ghana
Tel: +233 (0) 26-889-9759
Fax: +233 (0) 30-254-2756
E-mail: stoansah@yahoo.com

*Corresponding author 


\section{The Effect of Timeliness and Credit Ratings on the Information Content of Earnings Announcements}

ABSTRACT This paper investigates the impact of timeliness and credit ratings on the information content of the earnings announcements of Greek listed firms for a period spanning from 2001 to 2008. Using both the classical event study methodology and regression analysis, we find that firms tend to release "good news" on time and are inclined to delay "bad news". We also provide evidence that the level of corporate risk differentiates the information content of earnings according to the credit rating category. Specifically, firms displaying high creditworthiness enjoy positive excess returns on earnings announcement dates. In contrast, firms with low creditworthiness undergo significant share price erosions on earnings announcement days. We also observe a substitution effect between timeliness and credit ratings in relation to the information content of earnings announcements. Thus, we find that as the credit ratings of earnings-announcing firms improve, the informational role of timeliness is mitigated.

Keywords: Earnings announcements, credit ratings, timeliness, information asymmetry, Athens Stock Exchange.

JEL Classification Codes: G14; G15 


\section{Introduction}

Corporate events that transmit management expectations and private information to investors have been at the epicenter of market participant interest for several decades. The release of financial results remains one of the most puzzling features in accounting and finance research. Their importance is evident from the behavior of market participants such as managers, shareholders, investors, auditors and public authorities. Earnings disclosures have been proven to attract much media coverage, cause financial analysts to revise their estimations and to rejuvenate investor interest in capital markets. Since the seminal papers of Beaver (1968) and Ball and Brown (1968), who probed into the effects of earnings announcements on share prices, a strand of studies has attempted to disentangle the information content of financial results. Considering the timing of managers' decisions to release these results, prior research suggests that the dissemination of "bad news" tends to be delayed until it becomes unavoidable (e.g., Patell and Wolfson, 1982; Leventis and Weetman, 2004; Kothari et al., 2009; Crabtree and Kubick, 2014), while the acceleration of "good news" is to be expected. According to Crabtree and Kubick (2014), several theories have been propounded in the literature to construe the "good news early, bad news late" hypothesis, including: (i) proprietary reporting costs (Verrecchia, 1983); (ii) the desire to widen the time interval before disclosing "bad news" (Doyle and Magilke, 2009); and (iii) long horizon-related career concerns (Kothari et al., 2009). Thus, managers strategically decide on the release of "news" by considering the costs related to competitors' reaction and litigation (Verrecchia, 1983), information dissemination strategies regarding media and investor attention (Doyle and Magilke, 2009), and career implications (e.g., compensation and employment opportunities [Kothari et al., 2009]). 
Although the role of earnings disclosures has been extensively examined, it still remains a first order issue for many academics, investors and managers in the wake of increasingly opportunistic earnings management and the subsequent decline in accounting information quality (Jorion et al., 2009). The effect of the increase in earnings management has been the decline in the credibility of financial statements. As a result, an increasing number of investors and financial analysts have been looking for alternative channels of corporate information, such as credit ratings. Credit ratings transmit sensitive information to investors and financial markets beyond other publicly available information (Ederington and Goh, 1998; Jorion et al., 2005; Tang, 2009) since they provide assessments of a firm's financial creditworthiness for the foreseeable future. Moreover, credit rating agencies uncover qualitative information through due diligence processes and private communications with firm managers (Chou, 2013). Therefore, credit ratings include private forward-looking information that can be used by investors to better evaluate earnings news.

While credit ratings are commonly employed for assessing the creditworthiness of issuers of government and corporate bonds, there is an ongoing criticism regarding the accuracy of the ratings, their reputation, their incremental value and the credibility of their announcements ${ }^{1}$ (Kliger and Sarig, 2000; Boot et al., 2006; Benmelech and Dlugosz, 2009; Mathis et al., 2009; Mariano, 2012). These criticisms are particularly true within the European Union (EU), where the operations of credit rating agencies have been severely criticized and are currently under review by the EU parliament (Mackenzie, 2012). Nevertheless, credit ratings are considered a valuable source of corporate information by market participants. An and Chan (2008) argue that credit ratings assist in disseminating important information regarding firm value to uninformed investors and for that reason they reduce information asymmetry in financial markets. Boot et al. 
(2006) analytically show that credit rating agencies create information that accelerates the dissemination of private information to the market. On the basis of their analysis, we argue that credit ratings can also speed up the announcement of earnings in cases where the conveyed information heads in the same direction (e.g., "good news" for net income and creditworthiness). However, these supplementary effects may diverge when the two signals point in different directions. In this case, a substitution effect might be present since the role of credit ratings may alleviate the informational role of earnings announcements and vice versa.

Motivated by the studies of Liu and Malatesta (2006) and An and Chang (2008) that investigated respectively the informational role of corporate credit ratings around seasoned equity offerings (SEOs) and initial public offerings (IPOs), we extend the literature by examining the effects of corporate credit ratings on the information content of the earnings announcements of Greek listed firms. Additionally, we examine whether credit rating changes are informative with respect to the reaction of a firm's share price to the disclosure of its financial results. Finally, we explore the interrelationship between a firm's credit ratings and the timeliness of earnings announcements (i.e., the length of time between the actual earnings announcement date and the last fiscal year-end). This will help us to detect any possible supplementary or substitution effect of the two channels of corporate information.

Our interest in assessing the impact of credit ratings on earnings announcements is justified by the following three reasons. First, credit ratings appear to influence managerial decision-making. Specifically, managers adjust corporate capital structure based on credit rating levels (Kisgen, 2006). Consequently, credit ratings affect a company's level of debt, interest payments, profitability, and financial stability. Credit ratings also affect corporate operations. For example, long-term supply contracts may require firms to maintain a specific credit rating at the 
expense of growth and future profitability (Bosch and Steffen, 2011). Second, credit ratings play a significant role in the investment decisions of institutional investors (Bosch and Steffen, 2011). Credit rating agencies certify the quality of the borrower (Megginson and Weiss, 1991) and regulations may require investment only in highly-rated securities (Bosch and Steffen, 2011). Moreover, prior evidence shows that credit ratings influence market prices and thus capital gains (Griffin and Sanvicente, 1982; Yi and Mullineaux 2006; Hand et al., 1992; Tang, 2009). Third, "firms having higher level and lower variability of future earnings enjoy high credit ratings which enable the market to capitalize more future earnings news" (Chou, 2013, p. 218). Therefore, relevant decisions on credit ratings are expected to affect the informational content of earnings disclosures and provide strong signals about corporate issues to market participants.

To investigate the interactive effects of timeliness and credit ratings on the information content of earnings announcements, we employ data from firms listed on the Athens Stock Exchange (ASE) during the period of 2001-2008. Two remarkable events took place in Greece during this period that make it worthwhile a subject of an empirical study. First, following the European Commission's Financial Services (ECFS) 1999 directive on quarterly financial reporting, the Greek stock market regulator, the Hellenic Capital Markets Commission (HCMC), has directed Greek firms to make financial reports public on a quarterly basis since 2000 . This directive on quarterly financial reporting was expected to reduce information asymmetry between informed and uninformed investors in Greece. Informed investors consist of insiders and institutional owners who possess privy information about a firm's financial status and operations. Insiders are actively involved in managing the firm and so they rely less on financial statements to derive information regarding corporate events (Tzovas, 2006). Institutional investors, while not having the same access to private information compared to insiders, can 
create an informational advantage through their ability to expend more resources on gathering and processing information about companies (Amihud and Li, 2002). Through quarterly financial reporting the information gap between informed and uninformed investors shrinks as long as more corporate information is released and less non-public information is withheld. So new information is beneficial to uninformed investors but also to informed ones since it provides a basis for the latter group to verify their expectations and prior projections. As a result, more accurate financial projections are launched by equity analysts that may help both informed and uninformed investors to better evaluate a firm's future prospects.

Second, during the period under investigation, Greek financial reporting practices were blamed for excessive earnings management (Leuz et al., 2003; Garcia-Osma and Pope, 2011) and fraudulent reporting practices (Caramanis and Lennox, 2008). While several measures to restore investor confidence were initiated, such as the establishment of a new Oversight Board in 2003 and the early application of IFRSs under the Law 2992/2002, the local press and interviews with investment bankers revealed that investors in Greece used alternative channels other than annual reports to glean corporate information (including credit ratings and analyst recommendations). Hence, Greece provides an interesting setting for testing the informational role of credit ratings in association with earnings announcement releases. To isolate the effect of the country's sovereign debt crisis, which severely affected corporate creditworthiness and profitability, we focus our attention on the period just prior to the debt crisis, when market participants evaluated company fundamentals and corporate announcements without serious behavioral biases.

Our findings suggest that timeliness is a significant factor in making earnings announcements value-relevant, lending support to the "good news early, bad news late" 
hypothesis. In particular, firms that announce their earnings early experience positive excess returns, while firms announcing their earnings late undergo negative abnormal returns. The informativeness of earnings announcements becomes stronger when the early announcements contain positive earnings news. When the role of credit ratings is considered in our analysis, we find that the level of credit quality magnifies the value relevance of earnings announcements, especially when these contain positive earnings news and are released on a more timely basis. We also find an asymmetric market reaction to credit rating downgrades and upgrades, with the former inducing a stronger market reaction compared to the latter, and this reaction becomes even stronger when changes in credit ratings are congruent with changes in earnings (i.e., upgrades with positive earnings, downgrades with negative earnings). Finally, we empirically demonstrate a substitution effect between timeliness and credit ratings in relation to the information content of earnings announcements. Specifically, the informational role of timeliness is mitigated in cases of highly-rated firms, while for middle or low-rated firms it is magnified.

Our research contributes to the ongoing debate over earnings announcements in several ways. First, although the market reaction to earnings releases is well documented, the effects of credit ratings on the informational role of financial reports have not been directly examined before. Jiang (2008) was the first to investigate whether beating earnings benchmarks reduces the cost of debt, as proxied by credit ratings. However, our study differs from that of Jiang (2008) in that we examine the role of credit ratings in transmitting credible information to investors. Second, this is the first study that tests the role of timeliness in association with credit ratings. This allows us to investigate possible concurrent or opposing effects between the two sources of share price variation. The results show that the two effects relate to substitution rather than being complementary. Third, given the scant evidence regarding the role of credit ratings in equity 
markets, the current study highlights the importance of credit ratings as an alternative conduit of information for both informed and uninformed investors. The remainder of the paper is organized as follows: Section 2 develops the testable hypotheses. Section 3 describes the data and research methods employed. The results are presented and discussed in section 4, while section 5 presents the main conclusions of the paper.

\section{Literature review and hypotheses development}

\subsection{Timeliness of Financial Reporting}

Timeliness of financial reporting has been recognized as an important qualitative characteristic of accounting information and, as a consequence, has been included as an element of many conceptual frameworks for financial reporting (Epstein and Jermakowich, 2007). In May 1999, the ECFS advocated for quarterly reporting which eventually led to the EU's Transparency Directive (Directive No. 2004/109/EC). This Directive requires firms listed in the EU member states to report their financial performance and liquidity, among other things, on a quarterly basis. However, the EU did not mandate quarterly reporting, but rather encouraged voluntary adoption which, in effect, left it to each member state to decide whether to require firms in their respective countries to report on a quarterly or semiannual basis, considering the trade-off of costs and benefits involved. As a consequence, each member state was at liberty to set its own rules regarding the content of quarterly financial statements and whether to require firms to release financial reports for the first and third quarters (Alves and Dos Santos, 2008). This led to a situation where some EU member states (such as Austria, Finland, Greece, Italy, Portugal, Spain, and Sweden) require quarterly reporting, while others (such as Denmark, France and Germany) do not. 
The Greek market regulator, the HCMC, requires all listed firms in the country to release their annual earnings in the first three months after the financial year-end and to release interim earnings within two months after the end of each quarter. According to Chen et al. (2005), the time constraint for the announcement of earnings can create time pressure resulting in a heterogeneous market reaction. In fact, while the business press has provided many cases of the delayed announcement of "bad news", the extant academic literature has propounded several managerial incentives for withholding the release of negative financial results ("bad news") for various reasons. First, in the absence of an opportunity to hide "bad news" due to regulatory restrictions, managers will delay an announcement in the hope that it will filter slowly into stock prices (Watts and Zimmerman, 1978). Indeed, Doyle and Makilge (2009) provide evidence suggesting that "bad news" is released with some delay and that the market disseminates such information more broadly. Second, if managerial performance evaluation is related to earnings, managers will delay "bad news" to buy time in order to prepare a plan to respond to critics (Laurie and Pastena, 1975; Kross, 1981; 1982; Bowen et al., 1992). Alternatively, or probably additionally, managers delay "bad news" in order to gain more time to prepare a plan to reverse the poor performance (see Begley and Fischer, 1998). Third, managers may withhold "bad news" in the hope that over the next period some other favorable corporate events will occur to overshadow or obscure the negative information contained in the negative earnings announcement (Verrechia, 1983). Finally, career concerns can motivate managers to withhold "bad news" and gamble that subsequent events will allow them to "bury" it (see Kothari et al., 2009). Career concerns broadly encompass the implications of news on management compensation, promotion, employment opportunities within and outside the firm, and board interlocks (ibid.). 
Indeed, prior studies provide ample empirical evidence to support the "good news early bad news late" hypothesis (see Pastena and Ronen, 1979; Patell and Wolfson, 1982; Chambers and Penman, 1984; Begley and Fischer, 1998; Owusu-Ansah, 2000; Leventis and Weetman, 2004; Kothari et al., 2009). Haw et al. (2000) demonstrate that withholding "bad news" causes a gradual decline in stock prices, which is less costly to managers vis-à-vis a sharp fall in stock prices. Dye and Sridhar (1995) find that managers delay the release of "bad news" until favorable industry-wide news is announced. Based on theoretical propositions and empirical results, we expect firms that accelerate the publication of earnings to experience a share price appreciation, while those that delay the release of earnings will encounter firm value erosion. Moreover, we conjecture that the positive content ("good news") of financial reports provokes strong positive abnormal returns, while the negative ("bad news") content of earnings produces significant value losses. On the basis of the above discussion, we anticipate that firms that combine early announcements with "good content" bring about a considerable positive market reaction, whereas firms that delay the release of "bad news" suffer significant share price losses. Thus, our first hypotheses is as follows:

$\mathbf{H}_{1}$ : Ceteris paribus, firms with "good news" that accelerate the disclosure of earnings experience a positive abnormal market reaction, while those with "bad news" that delay the release of earnings experience a negative abnormal market reaction. 


\subsection{Importance of Credit Ratings}

The role of credit ratings is pivotal in financial markets. A strand of studies has examined the impact of credit ratings on the debt market, suggesting that credit rating agencies: (i) certify the quality of the borrower (Megginson and Weiss, 1991); (ii) impact on the cost of debt (Whited, 1992; Kaplan and Zingales, 1997); (iii) lessen credit constraints which enables rated firms to raise more debt capital (Faulkender and Petersen, 2006); (iv) impact on managerial decisions regarding corporate capital structure (Kisgen, 2009); and (v) increase the magnitude of syndicated loans, which enables firms to finance new investments and acquisitions (Sufi, 2009).

It has been suggested that the role of credit ratings in equity markets is comparable to that of debt markets (Chou, 2013). The reason for this is twofold. Firstly, credit ratings consider all publicly-available information. Aman and Nguyen (2013, p. 15) demonstrate that greater disclosure and transparency of earnings impacts on the accuracy of the rating. Secondly, credit ratings convey private information about the success of a firm's projects and probable future prospects that is not available to equity analysts (Ederington et al., 1987; Chou, 2013) and, therefore, they generate information that speeds up the divulgence of private information to the market (Boot et al., 2006). Such information is considered relevant to decision-making since credit rating agencies have the power to gather confidential non-public information which managers may hesitate to disclose publicly for reasons of proprietary costs (Kisgen, 2009). Indeed, Chou (2013) demonstrates that credit rating agencies are less biased in their firm evaluation and information disclosure compared to equity analysts (whose incentives are linked to the investment banking business).

To some extent, credit ratings determine the success of a firm (Mariano, 2012), since a bad credit rating increases the cost of debt which can damage the firm (Kliger and Sarig, 2000). 
Furthermore, downgrades (upgrades) in credit ratings can lead to significant negative (positive) effects on stock and bond returns (Hand et al., 1992). This is because institutional investors (e.g., broker-dealers, banks, insurance firms, pension funds etc.) are required or encouraged to invest in securities that receive acceptable ratings (White, 2002). Additionally, herding behavior has been suggested to be associated with credit rating decisions, particularly in markets where information asymmetry is pronounced (Mariano, 2012). Thus, corporate managers target credit ratings in making capital structure decisions (Kisgen, 2006; 2007).

While the information content of credit rating announcements has been well documented by prior studies (e.g., Holthausen and Leftwich, 1986; Goh and Ederington, 1993; Dichev and Piotroski, 2001) there is a paucity of evidence regarding the role of credit ratings in predicting the market reaction surrounding the release of new information ${ }^{3}$. For example, Liu and Malatesta (2006) and An and Chan (2008) explored the informational role of credit ratings surrounding SEOs and IPOs respectively and found that issuing firms with credit ratings encounter less underpricing that those without credit ratings. More recently, Chou (2013) examined whether credit ratings help stock prices to reflect more future earnings using the future earnings response coefficient model. In this study, we go a step further by assessing the effect of credit ratings ${ }^{4}$ on the information content of financial reports. We opt for analyzing this effect for a number of reasons. First, credit ratings affect the profitability of firms through interest payments. Firms with low credit quality face difficulties in raising funds through debt issue and, if they are able to raise funds, they normally do so at higher costs. Second, credit ratings determine the access to debt and equity markets and thus have a direct impact on a firm's capital structure (Faulkender and Petersen, 2006). Third, credit ratings are considered to be selective channels of corporate information for both informed and uninformed investors (Jorion et al., 2005). This becomes more 
evident in cases where firms enjoy high credit ratings which make them more transparent in terms of information disclosure compared with those with low credit ratings. The transparency is linked to a reduced amount of information asymmetry (Liu and Malatesta, 2006; DeBoskey and Gillet, 2013; Chou, 2013) which helps investors to better decode the information content of earnings releases. Based on the above, we conjecture that if firms with high creditworthiness enjoy a lower cost of debt, reduced information asymmetry, more transparency and a low probability of default (as suggested by prior literature), they will announce more favorable information through earnings releases which will be reflected in share prices. Thus, we hypothesize that:

$\mathbf{H}_{2}$ : Ceteris paribus, the higher a firm's credit rating, the better the information content of its earnings and the stronger the market reaction to the announcement of its earnings.

\section{Data and Methodology}

\subsection{Sample Selection and Data Collection}

Our sample consists of 258 ASE-listed firms which have data on our test variables over the eight-year period, 2001-2008. We hand-collected the earnings announcement dates of these firms from daily financial press releases and the ASE website. We define the earnings announcement date as the date that an annual or quarterly financial report is made public. We extracted data on earnings (net income) for each sample firm from Thomson One. We also obtained daily-adjusted closing stock prices from DataStream to estimate the abnormal share price behavior around earnings announcement dates. Data for each firm's credit ratings were obtained from Amadeus. We excluded financial sector firms (i.e. banking, insurance, investment, and leasing firms) from our sample due to the unavailability of credit ratings. 
Following the classification of the Amadeus credit ratings system, we identified four discernible groups of firms based on their creditworthiness, namely "healthy firms", "balanced firms", "vulnerable firms" and "risky firms". The "healthy firms" enjoy ratings between AAA and A levels (highly-rated). Firms in this group have the capacity to meet their financial commitments. They are notably strong, creditworthy and are highly solvent. The second group ("balanced firms") consists of firms with credit ratings between BBB and BB. Though the capital structure of these firms is considered adequate, they are likely to face some ongoing uncertainties or exposure to adverse business and economic conditions. The third group of firms ("vulnerable firms") consists of firms with credit ratings between B and CCC. Firms in this group are vulnerable as their fundamentals are weak and more susceptible to adverse market events. The fourth group of firms ("risky firms") contains credit ratings between CC and D. In this group firms display high vulnerability, a low capacity to meet financial commitments and a high probability of insolvency. Table 1 provides a detailed description of the characteristics of each group of firms.

\section{[Insert Table 1 about here]}

Initially, we identified 4,290 earnings announcement dates during the examination period. To avoid the problem of thin trading 5 (i.e., stocks that trade infrequently), we excluded firms that had not had any share transactions for more than 100 days. We also excluded firms with missing data on net income and credit ratings. We mitigate the effect of outliers by deleting observations that are in the top or bottom $1.5 \%{ }^{6}$ of the distribution of abnormal returns as well as unexpected earnings. The final sample consists of 2,443 announcement dates, of which 635 are annual earnings announcements, 619 first quarter earnings announcements, 602 semi-annual 
earnings announcements, and 587 third quarter earnings announcements. Panel A of Table 2 reports the sample distribution for each quarter and year examined.

\section{[Insert Table 2 about here]}

Panel B of Table 2 displays the yearly distribution of earnings announcements according to the credit rating categories of the firms in the sample. The group of firms with a "balanced" credit rating has the highest number of earnings announcements (1,660 observations), followed by the group of "vulnerable" firms (384 observations), and then by the "healthy" group of firms (347 observations). The group classified as "risky" has the least number of observations (52 observations). Panel $\mathrm{C}$ of Table 2 shows the number of credit rating upgrades and downgrades that occurred during the period under examination. About $42 \%$ (364) of the firms had their credit ratings upgraded, while 58\% (428) had their credit ratings downgraded. In addition, Panel C presents the cardinal size of credit rating upgrades and downgrades. We define the cardinal size of a credit rating as the difference between the cardinal value of a new rating and that of an old rating. Following Jorion et al. (2005), we convert credit ratings into cardinal values measured by a 4-point scale (1 for "healthy" firms, 2 for "balanced" firms, 3 for "vulnerable firms" and 4 for "risky" firms).

Panel A of Table 3 describes the maximum period, measured in working days, within which Greek listed firms are required to release their financial results. Year 2005 was a transition period due to the implementation of the IFRSs. For this specific year, there was an extension in the regulatory deadline for disclosing first and second quarter earnings results. A further extension was given for the release of annual results for 2006, 2007 and 2008. 
Panel B of Table 3 displays the average number of working days which pass before annual and quarterly results are released. It is evident that, on average, our sample firms announce their earnings results some days earlier than the regulatory deadline. The average firm issues its annual and quarterly earnings announcements slightly more than 30 calendar days after its fiscal year-end.

\section{[Insert Table 3 about here]}

\subsection{Methodology}

To assess the market reaction to earnings announcements, we use the classical event study methodology, whereby we define the event day $(t=0)$ as the day of disclosure of a firm's earnings results. We use an estimation window of three days $(-1,0$ and +1$)$ consisting of the day immediately before and immediately after the event day (inclusive) to capture the market reaction to the disclosure, since the market reaction to earnings announcements occurs over a short time span. The use of an event period longer than three days has the consequence of normalizing or reducing the effect of the release of earnings announcements that we intend to capture.

The effect of new information on the value of a given equity stock, $i$, is measured by the difference between the actual return on day $t, \mathrm{R}_{i, t}$, and the expected return on that day, $\mathrm{E}\left(\mathrm{R}_{i, t}\right)$. This difference is called abnormal return, $\mathrm{AR}_{i, t}$, and is given as:

$$
\mathrm{AR}_{i, t}=\mathrm{R}_{i, t}-\mathrm{E}\left(\mathrm{R}_{i, t}\right)
$$

The expected return can be derived from estimating the market model as:

$$
E\left(R_{i, t}\right)=a+\beta^{*} R_{m, t}
$$


where: $R_{m, t}$ is the return on the market portfolio on day $t$ and serves as a proxy for the ASE General Index (ASEI), and $\alpha$ and $\beta$ are the Ordinary Least-Squares parameters using the 200 daily returns data ${ }^{7}$ prior to the event window. Chung and Lee (1998) and Kim et al. (1997) also used 200 daily returns data to estimate $\alpha$ and $\beta$ in their market model in order to compute market reaction to earnings announcements.

To investigate the effect of annual and quarterly (interim) earnings announcements across the event period, we compute average abnormal returns (AAR) for all firm portfolios using the formula below:

$$
\operatorname{AAR}_{p, t}=\frac{\sum_{t=1}^{N} \mathrm{AR}_{i, t}}{\mathrm{~N}}
$$

where: $A R_{i, t}$ is the actual abnormal return for earnings announcement firms and $N$ is the number of observations in a portfolio. We also compute cumulative average abnormal returns (CAARs) for the three-day event period as follows:

$$
\operatorname{CAAR}(t-1-t+1)=\sum_{t=t_{1}}^{t_{2}} \operatorname{AAR}_{t}
$$

To investigate the timeliness of the earnings announcements of Greek listed firms, we define the reporting lag of earnings announcements as the number of working days from the begging of the period (either annual or quarterly) to the actual date of the announcement. To this end, we follow Chen et al. (2005) by forming an announcement timing index (ATI) to proxy the reporting lag, which is defined as ATI $=n / \mathrm{N}$, where: $n$ is the $n$th first working day after firms are required by the regulatory agency to announce earnings (i.e., January 2 for annual earnings announcements, April 1 for first quarter, July 1 for second quarter, and September 1 for third quarter); and $N$ is the total number of working days in the regulatory interval for earnings 
announcements, depending on whether the announcement is for annual or quarterly earnings (i.e., January 2 to March 31 for annual earnings announcement, April 1 to May 31 for first quarter, July 1 to August 31 for second quarter, and September 1 to November 30 for third quarter).

Furthermore, we assess whether firms that experience positive unexpected earnings changes expedite their disclosure of earnings, while those that exhibit negative unexpected earnings changes delay their earnings announcements. Using the random walk model ${ }^{8}$, we define unexpected earnings changes (UE) as the difference between a firm's current year earnings $\left(\mathrm{E}_{i, t}\right)$ and its previous year earnings $\left(\mathrm{E}_{i, t-1}\right)$, which could be positive or negative. Thus:

$$
\mathrm{UE}=\mathrm{E}_{i, t}-\mathrm{E}_{i, t-1}
$$

The unexpected earnings change is positive if $E_{i, t}>E_{i, t-1}$, neutral if $E_{i, t}=E_{i, t-1}$, and negative if $E_{i, t}<E_{i, t-1}$.

\section{Empirical results}

\subsection{Timeliness of Earnings Announcements and Stock Price Reaction}

As mentioned earlier, the HCMC requires that all ASE-listed firms disclose both their annual and quarterly earnings during a pre-determined time interval. Panel A of Table 4 displays the results from the full sample of earnings announcements. We observe that the disclosure of financial results provokes a weak positive abnormal return of $0.036 \%$ on day 0 . The CAAR for three days is $-0.100 \%$ and not statistically significant at any conventional level. These results demonstrate that earnings announcements are not informative per se. However, when splitting the full sample of earnings announcements according to the content conveyed (positive vs. negative earnings changes), we find support for Hypothesis 1. In particular, financial disclosures with "good 
content" produce significant excess returns on day 0 of $0.323 \%(t=2.89)$ and a CAAR of the three days of $0.492 \%(\mathrm{t}=2.54)$. On the other hand, firms that announce negative unexpected earnings undergo price losses of $-0.217 \%$ on day 0 and of $-0.623 \%$ over the three days surrounding the announcement date $(\mathrm{t}=-2.63)$. The above results confirm the findings of prior studies that the information contained in financial results is the key driver of stock price variations surrounding the announcement date.

Another aspect of financial disclosures that has been widely explored in the past is timeliness. In this study we examine the impact of timeliness on the information content of earnings announcements, initially isolating the effect of the earnings component and then incorporating it into our analysis. Panel B of Table 4 displays the results for the timeliness of the earnings announcements analysis. To assess timeliness we use the mean announcement date, which is calculated by averaging across firms the number of days that elapse between the first day that financial disclosure is permitted (e.g., January 2 for annual results) and the actual earnings announcement date. We find that the earliest announcements exhibit statistically significant positive abnormal returns on day 0 of $0.415 \%(\mathrm{t}=3.66)$, while the latest announcers experience abnormal returns of $-0.088 \%$, though not statistically significant $(\mathrm{t}=-1.18)$.

We further examine the value relevance of the timeliness of earnings announcements considering the unexpected earnings component. The results show that firms announcing positive unexpected earnings before the mean announcement date experience a strong abnormal return on day 0 of $0.714 \%$, which is statistically significant at the 0.01 level. However, we find no statistically significant market reaction when firms announce negative unexpected earnings ( $0.057 \%$ on day 0$)$, which suggests that early-announcing firms presenting negative news do not undergo significant price losses. Firms that announce positive unexpected earnings after the 
mean announcement date earn positive abnormal returns of $0.155 \%$ on day 0 which is, however, less in magnitude compared to firms that announce their earnings early $(0.714 \%)$. The market reaction is strong in cases where earnings are released late and contain "bad news". In these cases the abnormal return on day 0 is $-0.283 \%$ and statistically significant at the 0.01 level.

To probe deeper into the effects of timeliness on earnings releases, we split the sample along the regulatory deadline. Panel $\mathrm{C}$ of Table 4 presents the results for the timeliness of all quarterly announcements according to the regulatory deadline (fiscal quarter-end). Firms releasing earnings reports before the regulatory deadline earn significant abnormal returns on day 0 of $0.237 \%(t=3.29)$. On the other hand, firms that delay the release of earnings reports until the last day (the regulatory deadline) experience significant negative abnormal returns on day 0 of $-0.378 \%(\mathrm{t}=-3.11)$. Moreover, firms that accelerate the announcement of earnings with favorable content experience a statistically significant abnormal return of $0.555 \%$ on day $0(\mathrm{t}=$ 5.71), while those that delay the announcement of earnings with unfavorable content until the last day undergo a statistically significant abnormal return of $-0.484 \%(\mathrm{t}=-3.01)$. Overall, these results suggest that the timeliness of earnings announcements per se can produce a significant market reaction. However, the role of timeliness grows stronger depending on the content of the financial results. In cases of early announcements the "good" content of earnings drives up stock prices, while in cases of delayed announcements the "bad" content of earnings drives stock prices down. The two effects of timeliness and earnings content are cancelled out in cases of "early bad" and "late good" announcements, sending a neutral signal to the market. Collectively, the above results lend support to the "good news early, bad news late" hypothesis.

\section{[Insert Table 4 about here]}




\subsection{Informativeness of Credit Ratings}

While prior empirical evidence suggests that credit ratings reduce information asymmetry and affect corporate profitability (An and Chan, 2008), we investigate whether credit ratings enhance the informativeness of financial reports. Table 5 presents the results from the effect of credit ratings on the information content of earnings announcements. For the group of "healthy" firms, we find a positive market reaction of $0.126 \%$ on the announcement date, although this is not statistically significant $(t=0.79)$. When we relate credit ratings with the unexpected component of earnings, we observe that the information content of earnings reports changes. In particular, for the group of "healthy" firms, positive unexpected earnings produce strong positive abnormal returns of $0.503 \%$ on the announcement date $(\mathrm{t}=2.55)$ and a CAAR of three days of $0.453 \%(\mathrm{t}=$ 1.33). In contrast, negative unexpected earnings provoke share price losses of $-0.260 \%(\mathrm{t}=-$ 1.10) and a CAAR of three days of $-0.777 \%(t=-1.90)$.

The group of "balanced" firms exhibits insignificant returns around earnings releases ( $0.090 \%$ on day 0$)$, which implies that the credit ratings for this group send a neutral signal to the market. However, when we consider the interaction of unexpected earnings changes and credit ratings for this group of firms, we find significant positive abnormal returns in the case of positive unexpected earnings $(0.430 \%$ on day 0 and $0.919 \%$ over three days), but a negative stock market reaction in the case of negative unexpected earnings $(-0.220 \%$ on day 0 and $0.629 \%$ over three days). These results suggest that firms from the "healthy" or "balanced" group generate a significant share price response to the earnings announcements during the three-day window, depending on the sign of earnings change (positive or negative). Therefore, for these two groups of firms the market places more emphasis on the financial report content rather than on credit ratings. 
The group of "vulnerable" firms experience marginally significant negative CAARs of $0.707 \%$ during the three-day window $(t=1.66)$. This negative reaction persists even in cases of positive earnings content for each of the three days of the event period. In fact, the CAAR of three days is $-1.117 \%$, statistically significant at the 0.05 level. Surprisingly, the market reaction is moderate in cases of negative earnings announcements $(-0.158 \%$ on day 0 and a CAAR of $0.378 \%$ ). This result implies that the market might have already adjusted to the bad content of earnings announcements for this low-rated group of firms. The lowest-rated firms ("risky") are generally those that are over borrowed, exposed to high interest expenses, have high debt and weak fundamentals. Therefore, regardless of the sign of the earnings release (positive or negative), credit ratings appear to determine the informativeness of financial statements. The market does not even perceive positive changes in earnings as an indicator of improvement in a "risky" firm's financial standing. The market conceives such improvement as a temporary phenomenon. As a consequence, the reaction of the market is negative even in cases of positive unexpected earnings (- $-0.680 \%$ on day 0 and a CAAR of $-2.881 \%$ for the three-day event period).

In sum, our results suggest that credit ratings do explain the information content of earnings announcements. However, the role of credit ratings is magnified when earnings components are included in our analysis. In fact, the earnings sign is the main determinant of the market reaction to financial disclosures in the first two groups of credit ratings (i.e., "healthy" and "balanced"). However, the informational role of earnings content is mitigated for those firms belonging to the last two categories of credit quality (i.e., "vulnerable" and "risky"). For these two groups of firms, credit ratings appear to overshadow the information content in earnings releases. Thus, even when companies announce positive unexpected earnings they still experience market value losses. As an implication of the above results, we can assert that 
managers should be concerned with increasing the overall creditworthiness of their firms rather than focusing on merely increasing profitability.

\section{[Insert Table 5 about here]}

Additionally, we examine the joint effects of the timeliness of earnings announcements and the creditworthiness of firms on the information content of earnings. In their theoretical work, Boot et al. (2006) demonstrated that credit ratings agencies compile credible private and public information which speeds up the dissemination of private information to the market. An and Chan (2008) argued that high credit ratings help firms to announce corporate news in a timely manner, since high creditworthiness reduces information asymmetry through the dissemination of important information to uninformed investors. Aman and Nguyen (2013) showed that the extent and timeliness of information disclosures are associated with higher credit ratings. This can be attributed to investor interest in better-quality and well-timed information which reduces risk and uncertainty and which is then reflected by better credit ratings. Contrarily, a longer time between the fiscal closing date and the release of financial reports can be linked to lower credit ratings, since the delay in disseminating information is considered as an attempt to conceal unfavorable news until this becomes unavoidable. We therefore expect credit ratings, in association with timeliness, to exert a combined effect on the information content of financial accounts.

The results from the interrelation between credit quality and timely earnings announcements are reported in Table 6. We observe that "healthy" firms enjoy positive (though statistically insignificant) abnormal returns regardless of the timing of the announcement. Specifically, "healthy" firms that are early (late) announcers elicit an abnormal return of $0.252 \%$ 
$(0.085 \%)$ on the announcement date. This result implies that the market might have already incorporated the "good" content of the financial reports of high-rated firms. However, when the earnings component is taken into account, the results show a significant market reaction for both early and late announcers with positive earnings content ( $0.445 \%$ and $0.578 \%$, respectively). The market reaction is negative in the case of firms which delay announcing "bad" news (-0.369\%).

Interestingly, the results for "balanced" firms show that the market applauds early earnings announcements by producing an excess return of $0.409 \%$ on day $0(t=2.86)$ and a CAAR of $0.850 \%$ during the three-day event period $(t=3.98)$. Contrarily, late announcing firms undergo mild price reductions during the three-day period surrounding the announcement date (CAAR of $-0.154 \%)$. As in the "healthy" group, the sign of earnings magnifies the signal sent by "balanced" firms through earnings releases. Thus, early (late) announcers with positive earnings content receive strong abnormal returns of $0.751 \%(0.271 \%)$ on day 0 , while those with negative content experience price reductions $(-0.012 \%$ and $-0.262 \%$ respectively).

While "vulnerable" firms that release financial results early enjoy higher price appreciations of $0.848 \%$ on day 0 , those that delay earnings announcements undergo significant share price losses of $-0.378 \%$ on day 0 . When taking into account the earnings component, we see a heterogeneous market reaction in contrast to the "balanced" group of firms. Late announcers with either good or bad earnings content experience significant share price losses of $0.504 \%$ and $-0.287 \%$, respectively. This result implies that credit ratings overshadow the effect of the earnings content for the group of firms with low creditworthiness. Moreover, looking into the interrelationship between timeliness and credit quality we observe a substitution effect. Specifically, the impact of timeliness gets stronger as credit quality deteriorates. For instance, timeliness seems to exert no effect on the information content of earnings in the highest-rated 
firms. The market does not react to the firm being on time or delayed. For the "healthy" group of firms, the earnings component is the key driver of market reaction. As the credit quality worsens, timeliness appears to some extent to determine the market reaction to earnings releases. In other words, for the low-rated group of firms ${ }^{9}$, timeliness could serve as the best channel for transmitting important corporate information to investors.

\section{[Insert Table 6 about here]}

The results of the analysis investigating the impact of changes in credit ratings on earnings announcements are reported in Table 7 . We identify 364 cases of credit rating upgrades and 428 cases of credit rating downgrades during the examined period. Following Jorion et al. (2005), we convert credit ratings into cardinal variables measured on a 4-point scale ( 1 for "healthy" firms, 2 for "balanced" firms, 3 for "vulnerable firms" and 4 for "risky" firms). We also identify two main credit rating gradation types: "within" and "across". The "within" type occurs when a firm's credit rating changes within the same band of ratings, i.e. a change from A to AA or vice versa. In contrast, the "across" type occurs when a firm's credit rating changes between different band of ratings (i.e., a change from A to B or vice versa).

Panel A of Table 7 shows that credit rating upgrades provoke a non-significant market reaction on day 0 of $0.211 \%$. However, when credit rating upgrades are taken into account together with positive unexpected earnings, we observe significant share price appreciations on day 0 of $0.433 \%$, which is statistically significant at the 0.05 level. The market reaction becomes stronger when the upgrade is an "across" type $(0.586 \%$ on day 0$)$ vis-à-vis a "within" type $(0.403 \%$ on day 0$)$. These results imply that the information content of earnings is magnified when the change in credit ratings is an upgrade. In other words, the market rewards positive 
earnings releases when they are associated with notable credit rating upgrades. On the other hand, the combination of credit rating upgrades and negative unexpected earnings is associated with a non-significant market reaction on day $0(-0.002 \%$ on day 0$)$. Moreover, neither the "within" nor the "across" type excite the market in any way. These results imply that credit upgrading is offset by the negative content of earnings releases.

Panel B of Table 7 documents the effect of credit rating downgrades on earnings announcements. Unlike the results from credit rating upgrades, credit rating downgrades bring about a significant share price erosion during the three-day event period (CAAR of $-0.580 \%$ ). This result is consistent with prior research which suggests that the market reacts significantly to downgrades (Holthausen and Leftwich, 1986; Hand et al., 1992; Goh and Ederington, 1993; Jorion et al., 2005). However, when credit rating downgrades interact with the sign of the change in earnings releases, the results change considerably. Specifically, the information content of positive earnings releases is eliminated when the credit rating of the announcing firm deteriorates. In fact, this result is comparable to that of the negative earnings releases and credit rating upgrades reported earlier. On the other hand, when credit rating downgrades are associated with bad earnings releases, this produces significant market value losses. Specifically, the combination of credit rating downgrades and negative earnings results brings about a $-0.468 \%$ reaction on day 0 . This negative market reaction is slightly higher when the downgrading is of the "across" type $(-0.489 \%$ on day 0$)$ as opposed to the "within" type $(-0.483 \%$ on day 0$)$. The above results partly support the proposition that changes in credit ratings reveal private information regarding a firm's value, and that credit rating upgrades (downgrades) are decoded positively (negatively) by the market when they are associated with positive (negative) unexpected earnings releases. 


\section{[Insert Table 7 about here]}

\subsection{Regression Analysis}

We perform a multivariate regression analysis to check the validity of the results already reported. Specifically, we estimate the Fama-MacBeth (1973) regression, which is immune to problems of cross-sectional dependence (Dichev and Piotroski, 2001), to detect the factors that affect the information content of earnings. In this analysis, we use either the average abnormal return (AAR) of earnings announcements on day 0 or the cumulative average abnormal return of three days (CAAR) of the full sample as the dependent variable and we control for: (i) the credit ratings level (Cardinal) that takes the value of 1 for "healthy" firms, 2 for "balanced" firms, 3 for "vulnerable" firms and 4 for "risky" firms; (ii) the unexpected earnings change ( $\Delta \mathrm{UE})$ that takes the value of 1 for a positive unexpected change and 0 otherwise; (iii) the timeliness variable (Timeliness) that takes the value of 1 for announcements before the regulatory deadline and 0 otherwise; (iv) the interaction between credit ratings and change in unexpected earnings $($ Cardinal $* \Delta \mathrm{UE}) ;(\mathrm{v})$ the interaction between timeliness and change in unexpected earnings (Timeliness* $\Delta \mathrm{UE}$ ); and (vi) the interaction between credit ratings and timeliness (Cardinal*Timeliness).

Panel A of Table 8 reports the results for the analysis investigating the determinants of abnormal returns on earnings announcements. The coefficient of Cardinal is negative and statistically significant at the 0.05 level. This result implies that the higher the cardinal value (i.e. the lower the credit quality), the lower the market reaction to earnings releases. As expected, the coefficient of unexpected earnings change ( $\Delta \mathrm{UE}$ ) is positive and statistically significant at the 0.05 level. This result is consistent with our earlier results, suggesting that the sign of earnings change has a strong impact on earnings announcements. In addition, timeliness has a positive and 
statistically significant coefficient at the 0.05 level. This result corroborates findings from prior research which suggest that the market reacts strongly to earnings reports that are released to the public early. Furthermore, the results show that the interactive term between timeliness and unexpected earnings change (Timeliness* $\Delta \mathrm{UE}$ ) positively affects the informational component of earnings, lending support to the "good news early, bad news late" hypothesis. However, the interaction between cardinal and unexpected earnings change and also the interaction between cardinal and timeliness are statistically non-significant. Interestingly, the positive and significant interaction between cardinal and timeliness, when the CAAR of three days is the dependent variable, suggests that, as creditworthiness deteriorates (higher cardinal values), timeliness plays a more significant role in conveying news to the public. The above results corroborate the findings of Table 6 regarding the observed substitution effect between credit quality and timeliness.

Panel B of Table 8 reports the results from the impact of credit rating upgrades and downgrades on the abnormal returns of earnings announcements. As before, we use either the average abnormal return (AAR) of earnings announcements on day 0 or the cumulative average abnormal return of the three-day event window (CAAR) as the dependent variable. Again, we control for: Cardinal Size, which is the cardinal value of the new rating minus the cardinal value of the old rating; unexpected earnings change ( $\Delta \mathrm{UE})$ which takes the value of 1 for a positive unexpected change and 0 otherwise; and credit rating change $(\Delta \mathrm{CR})$ which takes the value of 1 for a credit rating upgrade and 0 otherwise. The results show that the coefficients of both unexpected earnings change ( $\Delta \mathrm{UE})$ and credit ratings change $(\Delta \mathrm{CR})$ positively and significantly affect the market on earnings announcement dates. Cardinal Size seems not to significantly affect the market reaction. Overall, our findings suggest that the content of earnings releases, the time- 
lag of earnings dissemination and the creditworthiness of firms are all significantly associated with the informativeness of earnings announcements.

\section{[Insert Table 8 about here]}

\subsection{Sensitivity Tests}

To confirm the robustness of our results, we conduct three additional tests. First, we re-run the tests using the market-adjusted returns model (see Brown and Warner, 1985) to compute the abnormal share price reaction surrounding earnings announcement dates. Untabulated results show that the mean abnormal return on day 0 is $0.482 \%$ for firms announcing earnings reports before the mean announcement date and $-0.214 \%$ for those announcing their earnings late. When firms announce positive (negative) unexpected earnings we observe a statistically significant abnormal return of $0.793 \%(0.112 \%)$ for early announcers on day 0 . Late announcers experience an abnormal return of $-0.082 \%$ when disclosing unexpected positive earnings and $-0.320 \%$ when disclosing negative financial results. "Healthy" firms that announce positive (negative) financial results experience significant abnormal returns of $0.458 \%(-0.431 \%)$ on the announcement date. "Balanced" firms that announce positive (negative) financial results experience significant abnormal returns of $0.374 \%(-0.337 \%)$ on the announcement date. "Vulnerable" firms that disclose positive (negative) financial results experience significant price erosions of $-1.535 \%$ ($1.567 \%)$ over the three-day announcement period. Finally, "risky" firms that announce positive (negative) financial results experience insignificant abnormal returns of $-0.750 \%(-0.880 \%)$ on the announcement date.

Second, we re-assess the share price behavior based on the sign of the earnings figure (i.e. positive earnings versus negative earnings) in lieu of unexpected earnings changes. The 
results demonstrate significant share price appreciations of $0.262 \%$ on day 0 for firms experiencing positive earnings and $-0.563 \%$ for those announcing negative earnings. The same share price pattern is recorded in all categories of firms (i.e., "healthy", "balanced", "vulnerable" and "risky"). Third, we re-run the regressions by using earnings figures in lieu of unexpected earnings as a control variable. The results are qualitatively similar to those reported in Table 8 .

\section{Conclusions}

This paper examines the impact of timeliness and credit ratings on the information content of earnings announcements by employing data from the Greek stock market. The adoption of European directives (e.g., Transparency Directive No. 2004/109/EC) and regulatory reforms (such as the application of IFRSs and the establishment of ELTE, a new accounting oversight board) were aimed at improving the quality of financial reporting. However, lack of enforcement (Christensen et al., 2012) has resulted in marginal benefits (see Garcia-Osma and Pope, 2011). Thus, timely information is important in mitigating asymmetries, leaks and rumors (OwusuAnsah, 2000). Additionally, in such markets investors often follow "credible" channels of information such as credit ratings which sometimes leads to herding behavior (Economou et al., 2011). While the role of credit ratings in bond markets has been well-examined, the employment of credit ratings in equity markets remains under-researched. We therefore examine the impact of both timeliness and credit ratings on corporate earnings announcements.

Our results show that the timeliness of earnings announcements is indeed value relevant. In particular, we find evidence of a significant share price appreciation for firms that make their financial statements available to the public earlier than the regulatory deadline. The informativeness of earnings becomes stronger when the early announcements contain positive 
earnings news. The results for the analysis investigating the role of credit ratings indicate that the level of credit quality strengthens the value relevance of earnings announcements, especially when combined with the sign of earnings figures. When considering the interrelation between credit ratings and timeliness, we detect an interesting substitution effect between these two conduits of corporate information. In essence, the role of timeliness in determining the informational content of earnings results increases as the credit quality deteriorates. Finally, we find a heterogeneous market reaction to earnings announcements when they are associated with credit rating upgrades and downgrades. On the one hand, credit rating downgrades provoke a stronger market reaction compared to upgrades, especially when changes in credit ratings are in the same direction with earnings changes (i.e. upgrades with positive earnings, downgrades with negative earnings). On the other hand, when changes in credit ratings move in the opposite direction to changes in earnings results, we observe no abnormal returns. This implies that the two contradictory changes almost outweigh the information content of financial results.

Our study provides several contributions to the ongoing debate about earnings announcements. Firstly, we extend prior research by offering evidence regarding the impact of credit ratings on the informational role of financial reports. We provide new evidence about the role of credit ratings in transmitting credible information to investors and shareholders alike. Secondly, this is the first study that tests the role of timeliness in association with credit ratings. This allows us to investigate possible concurrent or opposing effects between the two sources of share price variation. Our results show that the two sources are involved in a substitution rather than a complementary effect. Thirdly, given the scant evidence regarding the role that credit ratings play in equity markets, the current study sheds light on the importance of credit ratings as an alternative conduit of information for both informed and uninformed investors. 
Our results have several implications. From a practical point of view, our analysis could be of interest to those who invest in managerial-entrenched firms and seek ways to increase their wealth. The results also demonstrate that, although financial reports might be informative, they are subject to criticism of low financial reporting quality. Moreover, our results might be useful to corporate managers who implement measures to improve their firm's credit ratings. Credit ratings seem to constitute alternative channels for corporate information in cases where corporate news such as earnings announcements "obscure" content from the public. For investors, the employment of credit ratings provides useful insights into how these can be applied to equity markets in order to assess corporate information.

The study has several limitations. First, we do not test for the effects of certain variables that have been found to be significant in explaining variations in earnings information, such as industry clustering, intangible intensity and earnings persistence. Second, due to the lack of data on credit ratings for firms in the financial sector, we could not include such firms in our analysis. Third, due to data unavailability regarding financial analyst earnings forecasts in Greece, we are not able to calculate the unexpected earnings as the difference between actual earnings per share minus the mean analyst consensus forecast. The results and limitations of the study provide avenues for further research. 


\section{Endnotes}

1. In a famous case, the ratings for the now defunct Enron remained at investment grade four days before it went bankrupt, despite the fact that credit rating agencies had been well aware of its problems for months (Borrus, 2002).

2. For example, there have been press releases concerning EADS, the parent company of the Airbus jet manufacturer, about postponing the news of delayed delivery of the new A380 jetliner from April 2006 to June 2006. This caused severe criticism of the managers which, in turn, led EADS to lose a quarter of its value (Kothari et al., 2009). For further examples and evidence see Burns and Kedia (2006) and Cheng and Warfield (2005).

3. Jiang (2008) probed into the causal effect of earnings on the cost of debt as proxied by credit ratings, but not the reverse effect.

4. We use credit rating data from Amadeus, one of the leading credit rating agencies on corporate creditworthiness in Europe.

5. According to Brown and Warner (1985), the non-synchronous trading problem may result in biased estimates of market model parameters.

6. Results remain similar at different thresholds (e.g., $1 \%$ and $2 \%$ ).

7. According to Bartholdy et al. (2007), the standard estimation period for thin markets is between 200 and 250 observations (i.e., about a year of trading prior to the three-day event period).

8. An alternative way of calculating unexpected earnings changes is to use the consensus of financial analyst forecasts as a benchmark (the expected earnings). However, financial analyst forecasts were available for only a very limited number of Greek listed firms. 
9. The number of firms belonging to the "risky" group is profoundly smaller compared to the other groups and, for this reason, solid conclusions could not be reached. Moreover, we cannot identify early announcing firms for this group of firms.

\section{Acknowledgements}

The authors would like to thank two anonymous referees for their helpful comments and suggestions. 


\section{References}

Alves, Carlos, and Texeira Dos Santos. 2008. "Do first and third quarter unaudited financial reports matter? The Portuguese case.” European Accounting Review 17 (2): 361-392.

Aman, Hiroyuki, and Pascal Nguyen. 2013. "Does good governance matter to debtholders? Evidence from the credit rating of Japanese firms." Research in International Business and Finance 29: 14-34.

Amihud, Yakov, and Kefei Li. 2002. "The declining information content of dividend announcements and the effect of institutional holdings." working paper, New York University.

An, Heng, and Kam Chan. 2008. "Credit ratings and IPO pricing." Journal of Corporate Finance 14 (5): 584-595.

Ball, Ray, and Phillip Brown. 1968. "An empirical evaluation of accounting income numbers." Journal of Accounting Research 6 (2): 159-178.

Beaver, William. 1968. "The information content of annual earnings announcements." Journal of Accounting Research 6: 67-92.

Begley, Joy, and Paul Fischer. 1998. "Is there information in earnings announcement delay?" Review of Accounting Studies 3 (4): 347-363.

Benmelech, Efraim and Jennifer Dlugosz. 2009. "The alchemy of CDO credit ratings." Journal of Monetary Economics 56 (5): 617-634.

Boot, Arnout, Todd Milbourn, and Anjolein Schmeits. 2006. "Credit ratings as coordination mechanisms." Review of Financial Studies 19 (1): 81-118.

Borrus, Amy. 2002. "The credit-raters: How they work and how they might work better." Business Week, April 8: 38-40. 
Bosch, Oliver, and Sascha Steffen. 2011. "On syndicate composition, corporate structure and the certification effect of credit ratings." Journal of Banking and Finance 35 (2): 290-299.

Bowen, Robert, Marilyn Johnson, Terry Shelvin, and David Shores. 1992. "Determinants of the timing of quarterly earnings announcements." Journal of Accounting, Auditing and Finance 7 (4): 395-422.

Brown, Steven, and Jerold Warner. 1985. "Using daily stock return: The case of event studies.” Journal of Financial Economics 14 (1): 3-31.

Burns, Natasha, and Simi Kedia. 2006. "The impact of performance-based compensation on misreporting." Journal of Financial Economics 79 (1): 35-67.

Caramanis, Constantinos, and Clive Lennox. 2008. "Audit effort and earnings management." Journal of Accounting and Economics 45 (1): 116-138.

Chambers, Anne, and Stephen Penman. 1984. "Timeliness of reporting and the stock price reaction to earnings announcements.” Journal of Accounting Research 22 (1): 21-47.

Chen, Gongmeng, Louis Cheng, and Ning Gao. 2005. "Information content and timing of earnings announcements." Journal of Business, Finance and Accounting 32 (1\&2): 65-95.

Cheng, Qiang, and Terry Warfield. 2005. "Equity incentives and earnings management." The Accounting Review 80 (2): 441-476.

Chou, Ting-Kai. 2013. "Information content ratings in pricing of future earnings." Review of Quantitative Finance and Accounting 40 (2): 217-250.

Christensen, Hans Bonde, Luzi Hail, and Christian Leuz. 2012. "Mandatory IFRS reporting and changes in enforcement." Working paper, The University of Chicago, Booth School of Business. 
Chung, Dennis, and Jason Lee. 2002. “Ownership structure and trading volume reaction to earnings announcements: Evidence from Japan.” Pacific-Basin Finance Journal 6 (1\&2): $29-48$.

Crabtree, Aaron, and Thomas Kubick. 2014. "Corporate tax avoidance and the timeliness of annual earnings announcements." Review of Quantitative Finance and Accounting 42 (1): 51-67.

DeBoskey David, and Peter Gillett. 2013. "The impact of multi-dimensional corporate transparency on us firms' credit ratings and cost of capital." Review of Quantitative Finance and Accounting 40 (1): 101-134.

Dichev, Ilia, and Joseph Piotroski. 2001. "The long-run returns following bond ratings changes." Journal of Finance 56 (1): 173-203.

Doyle, Jeffrey, and Matthew Magilke. 2009. "The timing of earnings announcements: an examination of the strategic disclosure hypothesis." The Accounting Review 84 (1): 157182.

Dye, Ronald, and Sri Sridhar. 1995. "Industry-wide disclosure dynamics". Journal of Accounting Research 33 (1): 157-174.

Economou, Fotini, Alexandros Kostakis, and Nikolaos Phillipas. 2011. "Cross-country effects in herding behavior. Evidence from four south European markets.” Journal of International Financial Markets, Institutions and Money 21 (3): 443-460.

Ederington, Louis, and Jeremy Goh. 1998. "Bond rating agencies and stock analysts: who knows what when." Journal of Financial and Quantitative Analysis 33 (4): 569-585.

Epstein, Barry, and Eva Jermakowicz. 2007. IFRS 2007 - Interpretation and Application of International Financial Reporting Standards. New Jersey: Wiley. 
Fama, Eugene, and James MacBeth. 1973. "Risk, return, and equilibrium: empirical tests." Journal of Political Economy 81 (3): 607-636.

Faulkender, Michael, and Mitchell Petersen. 2006. "Does the source of capital affect capital structure?" Review of Financial Studies 19 (1): 45-79.

Garcia-Osma, Beatrice, and Peter Pope. 2011. "Strategic balance sheet adjustments under firsttime IFRS adoption and the consequences for earnings quality." Working paper, Lancaster University, UK.

Goh, Jeremy, and Louis Ederington. 1993. "Is a bond rating downgrade bad news, good news, or no news for stockholders?" Journal of Finance 48 (5): 2001-2008.

Griffin, Paul, and Antonio Sanvicente. 1982. "Common stock returns and rating changes: A methodological comparison.” Journal of Finance 37 (1): 103-119.

Hand, John, Robert Holthausen, Richard Leftwich. 1992. "The effect of bond rating agency announcements on bond and stock prices.” Journal of Finance 47 (2): 733-752.

Haw, In-Mu, Daqing Qi, and Woody Wu. 2000. “Timeliness of annual report releases and market reaction to earnings announcements in an emerging capital market: The case of China.” Journal of International Financial Management and Accounting 11 (2): 108-131.

Holthausen, Robert, and Richard Leftwich. 1986. "The effect of bond rating changes on common stock prices.” Journal of Financial Economics 17 (1): 57-89.

Jiang, John. 2008. "Beating earnings benchmarks and the cost of debt." The Accounting Review 83 (2): 377-416.

Jorion, Philippe, Zhu Liu, and Charles Shi. 2005. "Informational effects of regulation FD: Evidence from rating agencies.” Journal of Financial Economics 76 (2): 309-330. 
Jorion, Philippe, Charles Shi, and Sanjian Zhang. 2009. "Tightening credit standards: The role of accounting quality." Review of Accounting Studies 14 (1): 123-160.

Kaplan, Steven, and Luigi Zingales. 1997. "Do investment-cash flow sensitivities provide useful measures of financing constraints?" Quarterly Journal of Economics 112 (1): 169-215.

Kim, Jeong-Bon, Itzhak Krinsky, and Jason Lee. 1997. "Institutional holdings and trading volume reactions to quarterly earnings announcements." Journal of Accounting, Auditing and Finance 12 (1): 1-14.

Kisgen, Doron. 2006. "Credit ratings and capital structure." Journal of Finance 61 (3): 10351072.

Kisgen, Doron. 2007. "The influence of credit ratings on corporate capital structure decisions." Journal of Applied Corporate Finance 19 (3): 65-73.

Kisgen, Doron. 2009. "Do firms target credit ratings or leverage levels?" Journal of Financial and Quantitative Analysis 44 (6): 1323-1344.

Kligler, Doron, and Oded Sarig. 2000. "The information value of bond ratings." Journal of Finance 55 (6): 2879-2902.

Kothari, S.P. Susan Shu, and Peter Wysocki. 2009. “Do managers withhold bad news?” Journal of Accounting Research 47 (1): 241-276.

Kross, William. 1981. "Earnings announcement and time lag." Journal of Business Research 9 (3): 267-281.

Kross, William. 1982. "Profitability, earnings announcement time lags, and stock prices." Journal of Business Finance and Accounting 9 (3): 313-328.

Laurie, Arlene, and Victor Pastena. 1975. "How promptly do corporations disclose their problems." Financial Analysts Journal 31 (5): 55-61. 
Leuz, Christian, Dhananjay Nanda, and Peter Wysocki. 2003. "Earnings management and investor protection: An international comparison.” Journal of Financial Economics 69 (3): 505-527.

Leventis, Stergios, and Pauline Weetman. 2004. "Timeliness of financial reporting: applicability of disclosure theories in an emerging capital market." Accounting and Business Research 34 (1): 43-56.

Liu, Yang, and Paul Malatesta. 2006. "Credit ratings and the pricing of seasoned equity offerings.” Working paper, University of Washington.

Mackenzie, Michael. 2012. "Non-profit credit rating agency challenge.” Financial Times, April 16.

Mariano, Beatriz. 2012. "Market power and reputational concerns in the ratings industry." Journal of Banking and Finance 36 (6): 1616-1626.

Megginson, William, and Kathleen Weiss. 1991. "Venture capitalist certification in initial public offerings.” Journal of Finance 46 (3): 879-903.

Owusu-Ansah, Stephen. 2000. "Timelines of corporate financial reporting in emerging capital markets: Empirical evidence from the Zimbabwe stock exchange." Accounting and Business Research 30 (3): 241-254.

Pastena, Victor, and Joshua Ronen. 1979. "Some hypotheses on the pattern of management's informal disclosures.” Journal of Accounting Research 17 (2): 550-564.

Patell, James, and Mark Wolfson. 1982. "Good news, bad news, and the intraday timing of corporate disclosures.” Accounting Review 57 (3): 509-527.

Sufi, Amir. 2009. "Bank lines of credit in corporate finance: An empirical analysis." Review of Financial Studies 22 (3): 1057-1088. 
Tang, Tony. 2009. 'Information asymmetry and firms' credit market access: Evidence from Moody's credit rating format refinement." Journal of Financial Economics 93 (2): 325351.

Tzovas, Christos. 2006. "Factors influencing a firm's accounting policy decisions when tax accounting and financial accounting coincide." Managerial Auditing Journal 21 (4): $372-$ 386.

Verrecchia, Robert. 1983. "Discretionary disclosure." Journal of Accounting and Economics 5: 179-194.

Watts, Ross, and Jerold Zimmerman. 1978. "Toward a positive theory of the determination of accounting standards." Accounting Review 53 (1): 131-156.

White, Halbert. 1980. "A heteroscedasticity consistent covariance matrix estimator and a direct test of heteroscedasticity." Econometrica 48 (4): 817-838.

White, Lawrence. 2002. "The credit rating industry: an industrial organization analysis." In: Levich, R.M., Majnoni, G., Reinhart, C. (Eds.), Ratings, rating agencies and the global financial system. Kluwer Academic Publishers: Boston.

Whited, Toni. 1992. "Debt, liquidity constraints, and corporate investment: Evidence from panel data." Journal of Finance 47 (4): 1425-1460.

Yi, Ha-Chin, and Donald Mullineaux. 2006. "The informational role of bank loan ratings." Journal of Financial Research 29 (4): 481-501. 
Table 1. Description of credit rating categories

\begin{tabular}{|c|c|c|}
\hline Category & Rating & Risk Assessment \\
\hline \multirow{3}{*}{$\begin{array}{l}\text { Healthy } \\
\text { firms }\end{array}$} & AAA & $\begin{array}{l}\text { The firm's capacity to meet its financial commitments is extremely } \\
\text { strong. The firm shows an excellent economic and financial flow } \\
\text { and fund equilibrium. }\end{array}$ \\
\hline & AA & $\begin{array}{l}\text { The firm has a strong creditworthiness. It also has a good capital } \\
\text { structure and economic and financial equilibrium. Difference from } \\
\text { "AAA" is slight. }\end{array}$ \\
\hline & A & $\begin{array}{l}\text { The firm has a high solvency. The firm is, however, more } \\
\text { susceptible to the adverse effect of changes in circumstances and } \\
\text { economic conditions than firms in higher rated categories. }\end{array}$ \\
\hline \multirow{2}{*}{$\begin{array}{l}\text { Balanced } \\
\text { firms }\end{array}$} & BBB & $\begin{array}{l}\text { Capital structure and economic equilibrium are considered adequate. } \\
\text { The firm's capacity to meet its financial commitments could be } \\
\text { affected by serious unfavorable events. }\end{array}$ \\
\hline & BB & $\begin{array}{l}\text { A firm rated "BB" is more vulnerable than companies rated "BBB". } \\
\text { Furthermore, the firm faces major ongoing uncertainties or exposure } \\
\text { to adverse business, financial or economic conditions. }\end{array}$ \\
\hline \multirow{2}{*}{$\begin{array}{l}\text { Vulnerable } \\
\text { firms }\end{array}$} & B & $\begin{array}{l}\text { The firm presents vulnerable signals with regard to its fundamentals. } \\
\text { Adverse business, financial or economic conditions will be likely to } \\
\text { impair the firm's capacity or willingness to meet its financial } \\
\text { commitments. }\end{array}$ \\
\hline & $\mathrm{CCC}$ & $\begin{array}{l}\text { A firm rated "CCC" has a dangerous disequilibrium in the capital } \\
\text { structure and in its economic and financial fundamentals There is a } \\
\text { high probability that adverse market events and inadequate } \\
\text { management could affect the firm's solvency. }\end{array}$ \\
\hline \multirow{3}{*}{$\begin{array}{l}\text { Risky } \\
\text { firms }\end{array}$} & $\mathrm{CC}$ & $\begin{array}{l}\text { The firm shows signs of high vulnerability. In the event of adverse } \\
\text { market and economic conditions, the firm's strong disequilibrium } \\
\text { could increase. }\end{array}$ \\
\hline & $\mathrm{C}$ & $\begin{array}{l}\text { The firm shows considerable pathological situations. The firm's } \\
\text { capacity to meet its financial commitment is very low. }\end{array}$ \\
\hline & $\mathrm{D}$ & $\begin{array}{l}\text { The firm no longer has the capacity to meet its financial } \\
\text { commitments. }\end{array}$ \\
\hline
\end{tabular}

Note: The Multi Objective Rating Evaluation (MORE) model is essentially used to determine the level of distress of industrial firms by using data included in financial statements. 


\section{Table 2. Distribution of earnings announcement dates per time year and rating category}

Panel A: No. of earnings announcements per quarterly interval

\begin{tabular}{|c|c|c|c|c|c|}
\hline Year & $\begin{array}{c}\text { Annual } \\
\text { (4th } \text { Quarter) }\end{array}$ & 1st Quarter & 2nd Quarter & 3rd Quarter & Total \\
\hline 2001 & 5 & 2 & 0 & 0 & 7 \\
\hline 2002 & 15 & 5 & 9 & 11 & 40 \\
\hline 2003 & 48 & 29 & 28 & 36 & 141 \\
\hline 2004 & 53 & 48 & 35 & 29 & 165 \\
\hline 2005 & 81 & 54 & 57 & 49 & 241 \\
\hline 2006 & 117 & 101 & 99 & 103 & 420 \\
\hline 2007 & 106 & 169 & 174 & 161 & 610 \\
\hline 2008 & $\underline{210}$ & 211 & $\underline{200}$ & 198 & 819 \\
\hline Total & $\underline{\underline{635}}$ & $\underline{\underline{619}}$ & $\overline{\underline{602}}$ & $\overline{587}$ & $\underline{2,443}$ \\
\hline
\end{tabular}

Panel B: No. of earnings announcements per credit rating category

\begin{tabular}{|c|c|c|c|c|c|}
\hline Year & "Healthy" Firms & "Balanced" Firms & "Vulnerable" Firms & "Risky" Firms & Total \\
\hline 2001 & 3 & 4 & 0 & 0 & 7 \\
\hline 2002 & 7 & 32 & 1 & 0 & 40 \\
\hline 2003 & 19 & 97 & 22 & 2 & 141 \\
\hline 2004 & 39 & 95 & 26 & 5 & 165 \\
\hline 2005 & 61 & 147 & 33 & 0 & 241 \\
\hline 2006 & 56 & 296 & 62 & 6 & 420 \\
\hline 2007 & 64 & 438 & 96 & 16 & 610 \\
\hline 2008 & 98 & 551 & $\underline{148}$ & $\underline{22}$ & 819 \\
\hline Total & $\underline{347}$ & $\underline{\underline{1,660}}$ & $\underline{\underline{384}}$ & $\underline{\underline{52}}$ & 2,443 \\
\hline
\end{tabular}

Panel C: Earnings announcements per credit rating changes

Upgrades

$\begin{array}{lrcrc}\text { Year } & \text { No. } & \text { Cardinal Size } & \text { No. } & \text { Cardinal Size } \\ 2001 & 0 & 0.00 & 0 & 0.00 \\ 2002 & 3 & 1.00 & 0 & 0.00 \\ 2003 & 4 & 1.00 & 21 & 1.14 \\ 2004 & 18 & 1.17 & 26 & 1.08 \\ 2005 & 40 & 1.25 & 30 & 1.10 \\ 2006 & 56 & 1.00 & 76 & 1.11 \\ 2007 & 109 & 1.21 & 125 & 1.30 \\ 2008 & \underline{134} & 1.28 & \underline{150} & 1.15 \\ \text { Total } & \underline{364} & & \underline{428} & \end{array}$

Notes: "Healthy" firms are those with credit ratings between A and AAA, "Balanced" firms have credit ratings between $\mathrm{BB}$ and $\mathrm{BBB}$, "Vulnerable" firms are those having credit ratings between CCC and B, and "Risky" firms are those with credit ratings between D and CC. Categorical credit ratings are converted into a cardinal variable measured on a 10-point scale (1 for a AAA rating, 2 for AA rating, etc.). The cardinal size is the difference between the cardinal value of a new rating and that of an old rating. 
Table 3. The average and maximum number of days before releasing financial results

\begin{tabular}{|c|c|c|c|c|}
\hline \multicolumn{5}{|c|}{ Panel A: The maximum number of working days before releasing financial results } \\
\hline Year & $1^{\text {st }}$ Quarter & $2^{\text {nd }}$ Quarter & $3^{\text {rd }}$ Quarter & $4^{\text {th }}$ quarter \\
\hline 2001 & 41 & 44 & 45 & 40 \\
\hline 2002 & 40 & 44 & 43 & 42 \\
\hline 2003 & 39 & 43 & 42 & 41 \\
\hline 2004 & 40 & 43 & 42 & 39 \\
\hline 2005 & 62 & 65 & 42 & 40 \\
\hline 2006 & 38 & 43 & 44 & 63 \\
\hline 2007 & 40 & 44 & 45 & 63 \\
\hline 2008 & 41 & 43 & 42 & 58 \\
\hline \multicolumn{5}{|c|}{ Panel B: The average number of working days before releasing financial results } \\
\hline Year & $1^{\text {st }}$ Quarter & $2^{\text {nd }}$ Quarter & $3^{\text {rd }}$ Quarter & $4^{\text {th }}$ quarter \\
\hline 2001 & 30 & $\mathrm{n} / \mathrm{a}$ & $\mathrm{n} / \mathrm{a}$ & 37 \\
\hline 2002 & 27 & 39 & 38 & 38 \\
\hline 2003 & 34 & 37 & 35 & 39 \\
\hline 2004 & 34 & 33 & 34 & 37 \\
\hline 2005 & 54 & 54 & 36 & 37 \\
\hline 2006 & 33 & 37 & 37 & 53 \\
\hline 2007 & 35 & 38 & 39 & 52 \\
\hline 2008 & 37 & 39 & 38 & 53 \\
\hline
\end{tabular}

Notes: The maximum number of working days to pass before releasing financial results are determined by Greek corporate law. Year 2005 was a transitional year (the implementation of the IFRS) for releasing annual and firstquarter financial results. $\mathrm{n} / \mathrm{a}=$ non-available. 
Table 4. Abnormal returns around earnings announcements dates

Panel A: Announcements by sign of earnings

Full sample

Full sample: positive unexpected earnings

Full sample: negative unexpected earnings

$\begin{array}{ccc}\text { Obs. } & \text { Day }-1 & \text { t-student } \\ 2,443 & -0.004 & -0.04 \\ 1,145 & 0.051 & 0.46 \\ 1,298 & -0.053 & -0.39\end{array}$

Day
0.036
$0.323 * *$

$0.323 *$

\section{t-student}

0.33

2.89

$-1.59$

\section{Day +1}

$-0.132$

0.118

$-0.353 * * *$

\section{t-student}

$-1.22$

1.06

$-2.58$

CAAR $(-1,+1)$ t-student $-0.100$

$0.492 * *$

$-0.623 * * *$

Panel B: Announcements by mean announcement date

Before mean announcement date

Before mean announcement date: negative unexpected earnings

After mean announcement date

After mean announcement date: positive unexpected earnings

After mean announcement date: negative unexpected earnings

$587 \quad 0.166$

$3200.341 * *$

$267-0.043$

$1,818-0.059$

$809-0.085$

$1,009-0.037$

\subsection{3}

$0.415 * *$

$0.714 * * *$

0.057

3.66

4.85

0.031

$0.300 *$

$-0.291$

0.25

1.95

$0.613 * * *$

$1.355^{* * *}$

$-0.276$

$-0.88$

$-0.088$

\subsection{5}

$-1.18$

$-0.88$

$-0.283 * * *$

1.42

$-0.205^{* * *}$

0.034

$-2.59$

0.28

$-0.352$

0.104

$-0.718 * *$

$-0.398 * * * \quad-3.82$

(2)

$\begin{array}{rr}1,599 & 0.064 \\ 784 & 0.149 \\ 815 & -0.018\end{array}$

0.95
1.60
-0.19

$0.237 * * *$
$0.555 * * *$
-0.070

3.29

$-0.167 * *$

0.160

2.19

0.134

$0.864 * * *$

$-0.481 * * * \quad-4.50$

$-0.569 * *$

0.81

Before regulatory deadline: positive unexpected earnings
Before regulatory deadline: negative unexpected earnings

$805-0.140$

$345-0.222$

$-1.32$

$-0.378 * * *$

$-0.67$

$-0.106$

$-0.004$

$-0.182$

$-0.79$

$-0.624$

$-0.463$ $-0.744$ $-0.54$

1.04

$-0.744$

0.01

On regulatory deadline: negative unexpected earnings

Notes: The mean announcement date is calculated by averaging across firms the number of days that elapse between the first day that financial disclosure is permitted and the actual date of announcement. Regulatory deadline is defined as the ultimate date of announcement by law. The regulatory deadline is March 31 of the next year for annual results, May 31 for the first quarter, June 30 for semi-annual results, and November 30 for the third quarter results. Abnormal returns are computed using the market model and unexpected earnings are calculated using the random walk model. We define the event period of announcement as the three days surrounding the announcement day (days -1, 0 and +1 ). Market model parameters $(\alpha$ and $\beta$ ) were estimated using 200 daily returns data prior to the event window.

$*, * *$ and $* * *$ denote statistical significance at the $10 \%, 5 \%$ and $1 \%$ levels, respectively. 
Table 5. Abnormal returns of earnings announcements by credit ratings

Healthy firms

Healthy firms: positive unexpected earnings

Healthy firms: negative unexpected earnings

Balanced firms

Balanced firms: positive unexpected earnings

Balanced firms: negative unexpected earnings

Vulnerable firms

Vulnerable firms: positive unexpected earnings

Vulnerable firms: negative unexpected earnings

Risky firms

Risky firms: positive unexpected earnings

Risky firms: negative unexpected earnings

"Healthy" firms are those with credit ratings between $\mathrm{A}$ and AAA, "Balanced"

credit ratings between CCC and B, and "Risky" firms are those with credit ratings between D and CC. Abnormal returns are computed using the market model. Unexpected earnings changes are computed using the random walk model. We define the event period of announcement as the three days surrounding the announcement day (days $-1,0$ and +1$)$. Market model parameters $(\alpha$ and $\beta$ ) were estimated using 200 daily returns data prior to the event window.

$*$, ** and $* * *$ denote statistical significance at the $10 \%, 5 \%$ and $1 \%$ levels respectively.

$\begin{array}{lclc}\text { Day }+1 & \text { t-student } & \text { CAAR }(-1,+1) & \text { t-student } \\ -0.357 * * & -2.22 & -0.154 & -0.56 \\ -0.167 & -0.85 & 0.453 & 1.33 \\ -0.551 * * & -2.34 & -0.777 * & -1.90 \\ & & & \\ 0.011 & 0.10 & 0.109 & 0.58 \\ 0.392 * * * & 3.24 & 0.919 * * * & 4.39 \\ -0.337 * * & -2.43 & -0.629 * * * & -2.63 \\ & & & \\ -0.443 * & -1.80 & -0.707 * & -1.66 \\ -0.771 * * * & -2.65 & -1.117 * * & -2.34 \\ -0.213 & -0.64 & -0.378 & -0.89 \\ & & & \\ -0.897 & -1.16 & -1.947 & -1.45 \\ -1.208 & -0.93 & -2.881 & -1.27 \\ -0.702 & -0.78 & -1.363 & -0.88\end{array}$

$-0.702$

$-0.680$

$-0.330$

$-0.60$

$-0.52$

$-0.78$

$-1.363$

$-1.27$ 
Table 6. Abnormal returns of earnings announcements by credit ratings, timeliness and unexpected earnings

\begin{tabular}{|c|c|c|c|c|c|c|c|c|c|}
\hline & Obs. & Day -1 & t-student & Day 0 & t-student & Day +1 & t-student & CAAR $(-1,+1)$ & t-student \\
\hline \multicolumn{10}{|l|}{ Healthy firms } \\
\hline Before mean announcement date & 118 & 0.114 & 0.53 & 0.252 & 1.33 & $-0.845 * * *$ & -3.35 & -0.480 & -1.04 \\
\hline i) Positive unexpected earnings & 67 & 0.364 & 1.44 & $0.445^{*}$ & 1.85 & $-0.554 * *$ & -2.04 & 0.255 & 0.48 \\
\hline ii) Negative unexpected earnings & 51 & -0.215 & -0.58 & -0.002 & -0.01 & $-1.228 * * *$ & -2.67 & $-1.445^{*}$ & -1.83 \\
\hline After mean announcement date & 219 & 0.089 & 0.60 & 0.085 & 0.48 & -0.112 & -0.63 & 0.062 & 0.21 \\
\hline i) Positive unexpected earnings & 105 & -0.041 & -0.20 & $0.578 * *$ & 2.04 & 0.051 & 0.19 & 0.588 & 1.40 \\
\hline ii) Negative unexpected earnings & 114 & 0.208 & 0.96 & $-0.369 *$ & -1.70 & -0.262 & -1.09 & -0.423 & -1.03 \\
\hline \multicolumn{10}{|l|}{ Balanced firms } \\
\hline Before mean announcement date & 420 & 0.140 & 1.07 & $0.409 * * *$ & 2.86 & $0.301 *$ & 1.96 & $0.850 * * *$ & 3.98 \\
\hline i) Positive unexpected earnings & 232 & 0.264 & 1.57 & $0.751 * * *$ & 4.12 & $0.626 * * *$ & 3.33 & $1.640 * * *$ & 4.38 \\
\hline ii) Negative unexpected earnings & 188 & -0.012 & -0.06 & -0.012 & -0.05 & -0.100 & -0.40 & -0.124 & -0.57 \\
\hline After mean announcement date & 1,217 & -0.040 & -0.50 & -0.023 & -0.26 & -0.092 & -1.00 & -0.154 & -0.72 \\
\hline i) Positive unexpected earnings & 547 & -0.004 & -0.04 & $0.271 * *$ & 2.26 & $0.286^{* *}$ & 2.05 & $0.552 * *$ & 2.55 \\
\hline ii) Negative unexpected earnings & 670 & -0.069 & -0.63 & $-0.262 * *$ & -2.13 & $-0.401 * * *$ & -3.33 & $-0.731 * *$ & -2.34 \\
\hline \multicolumn{10}{|l|}{ Vulnerable firms } \\
\hline Before mean announcement date & 49 & 0.615 & 1.52 & $0.848 * *$ & 2.22 & -0.074 & -0.19 & $1.389^{*}$ & 1.84 \\
\hline i) Positive unexpected earnings & 20 & 1.163 & 1.50 & $1.215^{*}$ & 1.81 & -0.576 & -1.02 & $1.802 *$ & 1.67 \\
\hline ii) Negative unexpected earnings & 29 & 0.209 & 0.52 & $-0.577 * *$ & -2.29 & 0.297 & 0.54 & -0.070 & -0.07 \\
\hline After mean announcement date & 332 & -0.153 & -0.90 & $-0.378 *$ & -1.92 & $-0.587 * * *$ & -2.77 & $-1.118 * * *$ & -2.60 \\
\hline i) Positive unexpected earnings & 138 & -0.306 & -1.24 & $-0.504 *$ & -1.70 & $-0.799 * *$ & -2.51 & $-1.609 * * *$ & -2.64 \\
\hline ii) Negative unexpected earnings & 194 & -0.044 & -0.19 & -0.287 & -1.10 & -0.437 & -1.54 & $-0.768 * *$ & -1.97 \\
\hline \multicolumn{10}{|l|}{ Risky firms } \\
\hline After mean announcement date & 49 & -0.537 & -0.71 & -0.525 & -0.65 & -0.842 & -0.99 & -1.904 & -1.11 \\
\hline i) Positive unexpected earnings & 19 & -1.060 & -0.71 & -0.723 & -0.46 & -1.248 & -0.74 & -3.031 & -1.18 \\
\hline ii) Negative unexpected earnings & 30 & -0.217 & -0.26 & -0.404 & -0.46 & -0.593 & -0.64 & -1.213 & -0.71 \\
\hline
\end{tabular}

Notes: "Healthy" firms are those with credit ratings between A and AAA, "Balanced" firms have credit ratings between BB and BBB, "Vulnerable" firms are those having credit ratings between CCC and B, and "Risky" firms are those with credit ratings between D and CC. Abnormal returns are computed using the market model. A mean announcement date is defined as the number of days that elapse between the quarter-end and the average date of announcement. Unexpected earnings changes are computed using the random walk model. We define the event period of announcement as the three days surrounding the announcement day (days $-1,0$ and +1 ). Market model parameters ( $\alpha$ and $\beta$ ) were estimated using 200 daily returns data prior to the event window.

$*$, ** and $* * *$ denote statistical significance at the $10 \%, 5 \%$ and $1 \%$ levels respectively. 
Table 7. Credit rating changes and the information content of earnings announcements

Panel A: Informational effect of credit rating upgrades

Credit rating upgrades

Credit rating upgrades "within" type

Credit rating upgrades "across" type

Upgrades and positive unexpected earnings

Upgrades "within" type and positive unexpected earnings

Upgrades "across" type and positive unexpected earnings

Upgrades and negative unexpected earnings

Upgrades "within" type and negative unexpected earnings

Upgrades "across" type and negative unexpected earnings

\begin{tabular}{rrrlccccc} 
Obs. & Day -1 & t-student & Day 0 & t-student & Day +1 & t-student & CAAR $(-1,+1)$ & t-student \\
364 & -0.144 & -0.71 & 0.211 & 1.04 & -0.115 & -0.57 & -0.049 & -0.14 \\
304 & -0.220 & -1.02 & 0.118 & 0.55 & -0.073 & -0.34 & -0.175 & -0.47 \\
60 & 0.239 & 0.53 & 0.681 & 1.52 & -0.329 & -0.74 & 0.590 & 0.76 \\
178 & -0.319 & -1.48 & $0.433^{* *}$ & 2.01 & 0.235 & 1.09 & 0.349 & 0.94 \\
149 & -0.359 & -1.58 & $0.403^{*}$ & 1.78 & 0.372 & 1.64 & 0.417 & 1.06 \\
29 & -0.113 & -0.19 & $0.586^{*}$ & 1.98 & -0.472 & -0.79 & 0.000 & 0.00 \\
186 & 0.022 & 0.08 & -0.002 & 0.08 & -0.450 & -1.52 & -0.429 & -0.84 \\
155 & -0.087 & -0.26 & -0.156 & -0.47 & -0.501 & -1.51 & -0.743 & -1.29 \\
31 & 0.568 & 0.92 & 0.770 & 1.25 & -0.196 & -0.32 & 1.142 & 1.07 \\
& & & & & & & & -0.52 \\
428 & -0.045 & -0.24 & -0.278 & 1.49 & -0.257 & -1.37 & $-0.580^{*}$ & -1.79 \\
359 & -0.053 & -0.27 & -0.295 & -1.49 & -0.227 & -1.15 & $-0.575^{*}$ & -1.68 \\
69 & -0.005 & -0.01 & -0.193 & -0.40 & -0.412 & -0.86 & -0.580 & -0.70 \\
205 & -0.128 & -0.55 & -0.072 & -0.31 & $-0.467 * *$ & -1.99 & $-0.668^{*}$ & -1.66 \\
171 & -0.168 & -0.64 & -0.088 & -0.33 & -0.416 & -1.58 & -0.673 & -1.47 \\
34 & 0.075 & 0.14 & 0.008 & 0.01 & -0.726 & -1.34 & -0.643 & -0.69 \\
223 & 0.031 & 0.11 & $-0.468 *$ & -1.72 & -0.063 & -0.23 & -0.500 & -1.06 \\
188 & 0.052 & 0.20 & $-0.483^{*}$ & -1.83 & -0.054 & -0.21 & -0.485 & -1.06 \\
35 & -0.083 & -0.10 & $-0.489^{*}$ & -1.89 & -0.108 & -0.14 & -0.680 & -1.42 \\
\hline
\end{tabular}

Panel B: Informational effect of credit rating downgrades

Credit rating downgrades

Credit rating downgrades "within" type

Credit rating downgrades "across" type

Downgrades and positive unexpected earnings

Downgrades "within" type and positive unexpected earnings

Downgrades "across" type and positive unexpected earnings

Downgrades and negative unexpected earnings

$-0.10-0.489 *$

$-1.89$



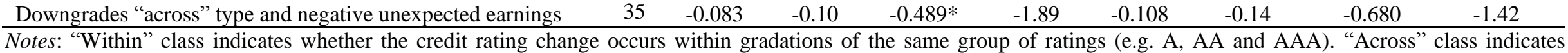

$-1.42$ changes in credit ratings that take place between different groups of firms (e.g. from "healthy" to "balanced"). Abnormal returns are computed using the market model and unexpected earnings are calculated using the random walk model. We define the event period of announcement as the three days surrounding the announcement day (days -1, 0 and +1$)$. Market model parameters $(\alpha$ and $\beta$ ) were estimated using 200 daily returns data prior to the event window.

$*, * *$ and $* * *$ denote statistical significance at the $10 \%, 5 \%$ and $1 \%$ levels, respectively. 
Table 8. Regression analysis

Panel A: Results for determinants of abnormal returns on earnings announcements

Model: AAR $(\mathrm{CAAR})=\beta_{0}+\beta_{1}$ Cardinal $+\beta_{2} \Delta \mathrm{UE}+\beta_{3}$ Timeliness $+\beta_{4}$ Cardinal $* \Delta \mathrm{UE}+$ $\beta_{5}$ Timeliness $* \Delta \mathrm{UE}+\beta_{6}$ Cardinal $*$ Timeliness $+\varepsilon$

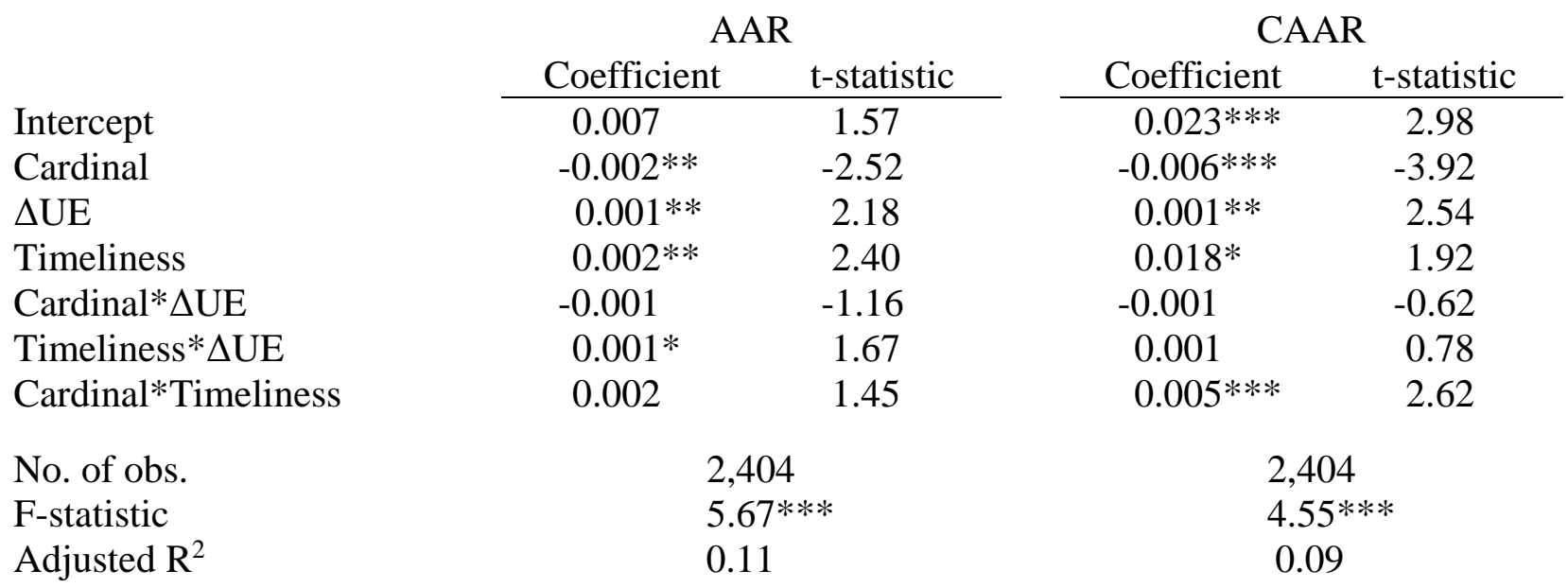

Panel B: Results for assessing credit rating upgrades and downgrades on earnings announcements

Model: $\mathrm{AAR}(\mathrm{CAAR})=\alpha_{0}+\alpha_{1}$ Cardinal Size $+\alpha_{2} \Delta \mathrm{UE}+\alpha_{3} \Delta \mathrm{CR}+\varepsilon$

\begin{tabular}{|c|c|c|c|c|}
\hline \multirow{3}{*}{ Intercept } & \multicolumn{2}{|c|}{ AAR } & \multicolumn{2}{|c|}{ CAAR } \\
\hline & Coefficient & t-statistic & Coefficient & t-statistic \\
\hline & $-0.006^{*}$ & -1.68 & -0.006 & -0.12 \\
\hline Cardinal Size & 0.001 & 0.44 & -0.004 & -0.74 \\
\hline$\Delta \mathrm{UE}$ & $0.005^{* *}$ & 2.06 & $0.003 *$ & 1.71 \\
\hline$\Delta \mathrm{CR}$ & $0.004^{*}$ & 1.74 & $0.005 * *$ & 2.22 \\
\hline No. of obs. & \multicolumn{2}{|c|}{792} & \multicolumn{2}{|c|}{792} \\
\hline F-statistic & \multicolumn{2}{|c|}{2.46} & \multicolumn{2}{|c|}{1.95} \\
\hline Adjusted $\mathrm{R}^{2}$ & \multicolumn{2}{|c|}{0.06} & \multicolumn{2}{|c|}{0.01} \\
\hline
\end{tabular}

Notes: Regression analysis is performed using the OLS with White's (1980) heteroscedasticity-consistent standard errors. The dependent variable is either the average abnormal return on the earnings announcement day (AAR) or the cumulative average abnormal returns of the three days around the earnings announcement date (CAAR). The independent variables are: the unexpected earnings change $(\triangle \mathrm{UE})$ that takes the value of 1 for a positive unexpected change and 0 otherwise; the timeliness dummy (Timeliness) that takes a value of 1 for announcements before the regulatory deadline and 0 otherwise; and the credit ratings level (Cardinal) that takes a value of 1 for "healthy" firms, 2 for "balanced" firms, 3 for "vulnerable" firms and 4 for "risky" firms. Cardinal* $\Delta U E$ is an interaction between credit ratings and change in unexpected earnings. Timeliness*UE is an interaction between timeliness and change in unexpected earnings. Cardinal*Timeliness is an interaction between credit ratings and timeliness. Cardinal Size of rating changes is the cardinal value of the new rating minus the cardinal value of the old rating. Credit rating change $(\Delta \mathrm{CR})$ takes the value of 1 for a credit rating upgrade and 0 otherwise.

$*, * *$ and $* * *$ denote statistical significance at the $10 \%, 5 \%$ and $1 \%$ levels respectively. 